\title{
A Review of Safety and Quality Issues in the Construction Industry
}

\author{
Amaka Chinweude Ogwueleka ${ }^{1}$
}

Received January 29, 2013 / Revised March 04, 2013 / Accepted June 19, 2013

\begin{abstract}
Construction industry is considered as the most hazardous industry due to its unique nature. Safety and quality management are essential to control hazards and improve success in project implementation. This paper focuses on evaluating the crucial factors influencing safety and quality management in construction projects. In order to achieve this, the qualitative and quantitative approaches were used for data collection. The findings of this study reveal the crucial safety factors as management commitment, safety awareness of top management practices/ procedures/reviews, and errors in judgement or carelessness. Project supervision, employee involvement/ altitude, and expertise knowledge/ training were considered as the crucial quality factors influencing safety and quality management. The study shows that safety and quality issues cannot be overlooked therefore proper implementation is paramount to achieve project success.
\end{abstract}

Keywords: safety factors, quality factors, project success, occupational injuries and construction employees

\section{INTRODUCTION}

Project implementation has documented tremendous success over the years due to the introduction of new technological methods (Ogwueleka, 2010).

Notwithstanding, construction projects have also recorded several work- related accidents and injuries (Aksom and Hadikusumo, 2008). Construction industry is considered as the most hazardous industry due to its unique nature. Globally, construction employees have three times more chances of dying and two times of getting injured than any worker of other economic activity (Sousa and Teixeira, 2004). In Nigeria, the statistics reveal that thousands of workers are being injured and even killed annually due to the industrial related accidents, where the construction industry has recorded twenty percent of the occupational injuries and fatalities (Federal Ministry of Works \& Housing Development, 2007). It is important to understand that a high proportion of workforce emanates from the construction industry when compared to other industrial sectors (ETA/ Business Relations Group Report, 2004). This implies that a large population of global workforce is prone to occupational injuries and fatalities. Stanley (2010) conveys that the majority of construction injury cases are simply related to poor decision making, which can be prevented through adequate safety culture. Correspondingly, Construction Engineering and Infrastructure Management (2010) reports on the study conducted by Dr Dung investigating the reasons for construction accidents in Vietnam. Poor quality and un-safety of different temporary structure systems are revealed as the major causes of construction injuries. Construction accidents may occur on a project site due to collapse of construction parts or elements, unsafe working areas, human behaviour and misuse of machineries (Abdelhamid and Everett, 2000). The adoption of health and safety culture is without doubt an essential element required in the construction process to influence project environment to realize its profitability or stipulated outcomes (Abdul-Raouf, 2004; Husin et al., 2008; Ogwueleka, 2011).

In this 21 st century, the increase in technological and social changes has also altered the pace of construction works where many other management practices are employed to reduce the occupational injuries and fatalities and improve efficiency and effectiveness of construction processes by eliminating waste and increase profit. These management practices are centred on quality and safety management philosophies, for example, CSHM web based system, OSHA VPP, OSHA Construction E-tool, OHSAS 18001 System and ISO 9001. The demand of clients has also advanced towards improving service quality, faster buildings and innovations in technology where quality management practices are designed to meet the clients' views of quality as well as complying with specifications. The integration of safety issues and quality provides a more comprehensive approach to the safety culture whilst at the same time achieving quality in construction (Husin et al., 2008). Krause (1994) and Cooper \& Phillips (1995) argue that safety is parallel to quality in one way relationship whereas, safety management can be improved through quality management processes, not the other way around. Recent studies have proved that safety leads to quality, where working safe can enhance performance likewise quality can support safety by reducing losses of assets (Husin et

${ }^{1}$ Department of Quantity Surveying, University of Uyo, Uyo, Nigeria, chinweogwueleka@yahoo.com (*Corresponding Author) 
al 2008; Stewart \& Townsend, 1999). The integration of safety and quality management will not only support each other but also they can be synergistic, thereby encouraging their mutual effectiveness. This is focused on meeting the clients' needs as well as reducing waste of resources. Despite the efforts to prevent occupational injuries and fatalities, construction workers still remain casualties. Chan and Tam (2000) attribute these problems to poor safety and quality measures which can be prevented through proper management of design complexities. This paper is focused on evaluating the crucial factors influencing safety and quality management in Akwa Ibom State of Nigeria.

\section{THE INTEGRATION OF SAFETY AND QUALITY MANAGEMENT}

Safety management involves the use of appropriate procedures towards the eliminating or reducing of accident occurrences and injuries and also damage to plants, equipments and adjoining properties (Anumba and Atkinson, 1997). While quality management is the optimization of efforts to ensure that the requirements are met efficiently and on the first attempt (Husin et al., 2008). Quality management has become a focal point in construction project; most stakeholders are concerned with the quality of their projects while contractors are more concerned with safety of their workers. Proper quality management can facilitate project success and organizational sustainability but negligence of safety culture can result in construction accidents and injuries. These occupational injuries and fatalities can affect the manpower output of workers, therefore reducing the probability that the job will be properly executed. Husin et al. (2008) emphasize that safety culture can lead to quality. For example, it is difficult for a mason to lay brick on a straight line if one hand is needed to hang onto the scaffold. The integration of safety and quality management system can reduce variability in the construction process such as failure of building elements, workers inefficiencies and injuries (Hoonakker, 2003). Several researchers have proved that the integration of both safety and quality management can improve productivity and occupational safety/ health and also minimize cost overruns (Schriener et al., 1995; Kuprenas and Kenney, 1998; Mckim and Kiani, 1995). The functions of safety and quality management are similar in several aspects such as scope, critical to success and goal, detection, obstacles and problem causes, response, effect of failure and difficult in optimizing the program (Husin et al., 2008). The similarities between safety and quality functions and their abilities to co-exist in the same environment are proofs that they can be easily integrated to produce positive effect.

\section{FACTORS INFLUENCING SAFETY AND QUALITY MANAGEMENT IN CONSTRUCTION PROJECTS}

It is essential to discover specific factors that are significantly important towards successful implementation of safety and quality programs to achieve desired outcomes. In the survey conducted by Tam et al (2004), the study reveals elements of poor construction safety management in China as lack of training, poor safety awareness of project managers, reluctance of input resources to safety and reckless operation. Client requirement, insurance company requirement and employee requirement were identified as criteria for safety management system implementation (Law et al., 2006). Coble and Kibert (1994) stipulate that construction accidents mostly occur on site due to inappropriate knowledge or training, errors in judgment or carelessness and poor machineries. These causes can be eliminated or reduced by adoption of safety performance indicators such as management commitment/ review, cost effectiveness/ time, communication, audits/ observations, strong safety culture/ climate, emphases on short-term objectives and employee involvement/ empowerment (Hoonakkar et al., 2003). European process safety centre (1994) specifies the core safety management elements as safety policy/ arrangement, organization, management practices and procedures, monitoring and auditing and management review. Smallwood (2000) highlights the most common barriers to safety implementation as lack of skilled workers, poor management commitment, workers altitude and type and nature of construction. Husin and Adnan (2008) list the threats to safety implementation as tight project schedule, low management competency, unsuitable planning, excessive approval procedures, unavailability of skilled labor, variations and lack of coordination between project participants. Customer requirement, insurance company requirement, employee requirement and cost effectiveness are regarded as safety management criteria (Pun and Hui, 2002; HarmsRingdahl et al., 2000; Sakvik and Nytro, 1996; Ashmore, 1995). Table I represents the summary of factors influencing safety management in construction projects.

The most common barriers to a successful quality management are lack of management/ leadership skills, poor understanding of customer/ client expectation, lack of worker empowerment/ incentive and nature of job or construction industry (Loushine and Hoonakker, 2002.). Hoonakker (2006) identifies quality indicators as teamwork, continuous improvement, management commitment, communication, customer or client focus, employment involvement/ empowerment. Husin and Adnan (2008) highlight the threats to quality management implementation as tight project schedule, inadequate scheduling, unsuitable construction planning, incomplete or inaccurate cost estimate, low management competency, variations, lack of coordination between project participants, unavailability of sufficient skilled labour. Supervision, relationship between project participants, bid selection process, training, quality policy and performance of quality tools are identified as quality factors (Arditi and Gunaydin, 1998). Chan and Tam (2000) state the major factors influencing quality performance in construction projects as planning process, design/ project complexities, nature uniqueness, availability of resources and project environment. 
TABLE I

SUMMARY OF FACTORS INFLUENCING SAFETY MANAGEMENT IN CONSTRUCTION PROJECTS

\begin{tabular}{|c|c|c|c|c|c|c|c|c|c|c|c|}
\hline Safety Factors & 1 & 2 & 3 & 4 & 5 & 6 & 7 & 8 & 9 & 10 & 11 \\
\hline Management Commitment & & $\mathrm{x}$ & & & & $\mathrm{x}$ & & & & & $\mathrm{x}$ \\
\hline Employee involvement/ altitude & & $\mathrm{x}$ & & & $\mathrm{x}$ & $\mathrm{x}$ & & & $\mathrm{x}$ & & $\mathrm{x}$ \\
\hline Errors in judgement or carelessness & $\mathrm{x}$ & & $\mathrm{x}$ & & & & & & & & \\
\hline Expertise knowledge or training & $\mathrm{x}$ & & $\mathrm{x}$ & & & $\mathrm{x}$ & & & & $\mathrm{x}$ & \\
\hline Poor machineries & $\mathrm{x}$ & & & & & & & & & & \\
\hline Communication & & $\mathrm{x}$ & & & & & & & & & $\mathrm{x}$ \\
\hline Audits/ observations & & $\mathrm{x}$ & & $\mathrm{x}$ & & & & & & & $\mathrm{x}$ \\
\hline Safety culture/ climate & & $\mathrm{x}$ & & & & & & & & & $\mathrm{x}$ \\
\hline Safety awareness of top management/ top managers & & & $\mathrm{x}$ & & & & & & & $\mathrm{x}$ & \\
\hline Reluctance of input resources to safety & & & $\mathrm{x}$ & & & & & & & & \\
\hline Safety policy/ arrangement & & & & $\mathrm{x}$ & & & & & & & \\
\hline Type/ nature of construction & & & & & & $\mathrm{x}$ & & & & & \\
\hline Safety management/ practices/ procedures/ review & & & & $\mathrm{x}$ & & & & & & $\mathrm{x}$ & \\
\hline Client involvement & & & & & $\mathrm{x}$ & & $\mathrm{x}$ & & & & \\
\hline Insurance company requirement & & & & & $\mathrm{x}$ & & & $\mathrm{x}$ & & & \\
\hline Cost-effective/ time & & & & & & & & & & & $\mathrm{x}$ \\
\hline Tight project schedule & & & & & & & & & & $\mathrm{x}$ & \\
\hline Improper construction planning/ programs & & & & & & & & & & $\mathrm{x}$ & \\
\hline \multicolumn{12}{|l|}{ Variations } \\
\hline Lack of coordination between project participants & & & & & & & & & & $\mathrm{x}$ & \\
\hline Employee empowerment & & & & & & & & & & & $\mathrm{x}$ \\
\hline Emphases on short-term objectives & & & & & & & & & & & $\mathrm{x}$ \\
\hline
\end{tabular}

TABLE II

SUMMARY OF FACTORS INFLUENCING QUALITY MANAGEMENT IN CONSTRUCTION PROJECTS

\begin{tabular}{|c|c|c|c|c|c|c|c|c|c|c|c|c|c|c|c|c|c|c|c|c|}
\hline Quality Factors & 1 & 2 & 3 & 4 & 5 & 6 & 7 & 8 & 9 & 10 & 11 & 12 & 13 & 14 & 15 & 16 & 17 & 18 & 19 & 20 \\
\hline Management/ leadership skills & $\mathrm{x}$ & & & & & & & & & & & & & & & & & & & \\
\hline $\begin{array}{l}\text { Interpretations of client } \\
\text { /customer expectations }\end{array}$ & $\mathrm{x}$ & & & & & & & & & & & & & & & & & & & \\
\hline Worker empowerment/incentive & $\mathrm{x}$ & & & $\mathrm{x}$ & & & & & & & & $\mathrm{x}$ & & & & & $\mathrm{x}$ & $\mathrm{x}$ & & \\
\hline Organization structure & & & & & & & & & & & & & & & & & $\mathrm{x}$ & & & \\
\hline Nature of construction & $\mathrm{x}$ & & & & & & & & & & & & & & & & & & & \\
\hline Continuous improvement & & & & & & & $\mathrm{x}$ & & & & & $\mathrm{x}$ & & & & & & & & \\
\hline Management commitment & & $\mathrm{x}$ & $\mathrm{x}$ & $\mathrm{x}$ & & & & & & & & & & $\mathrm{x}$ & & & $\mathrm{x}$ & & & \\
\hline Communication & & $\mathrm{x}$ & & & & & & & & & & & & & & & & & & \\
\hline Client/customer focus & & $\mathrm{x}$ & & & & & & & & & & & & & & & & & & \\
\hline Employee involvement/ altitude & & $\mathrm{x}$ & & $\mathrm{x}$ & & & & & & & & & & & & & & & & \\
\hline Tight project schedule & & & $\mathrm{x}$ & & & & & & & & & & & & & & & & & \\
\hline Inaccurate or incomplete estimate & & & $\mathrm{x}$ & & & & & & & & & & & & & & & & & \\
\hline Variations & & & $\mathrm{x}$ & & & & & & & & & & & & & & & & & \\
\hline Planning/ scheduling process & & & $\mathrm{x}$ & & $\mathrm{x}$ & & & & & & & & $\mathrm{x}$ & & & $\mathrm{x}$ & & & & \\
\hline $\begin{array}{l}\text { Coordination between project } \\
\text { participants }\end{array}$ & & $\mathrm{x}$ & $\mathrm{x}$ & & & $\mathrm{x}$ & & & $\mathrm{x}$ & $\mathrm{x}$ & & & & & & & $\mathrm{x}$ & & & \\
\hline $\begin{array}{l}\text { Expertise knowledge or training } \\
\text { system }\end{array}$ & & & $\mathrm{x}$ & $\mathrm{x}$ & & $\mathrm{x}$ & & & & & & & & & & & & $\mathrm{x}$ & $\mathrm{x}$ & \\
\hline Tendering and bidding climate & & & & $\mathrm{x}$ & & $\mathrm{x}$ & & & $\mathrm{x}$ & & & $\mathrm{x}$ & & & & & & & & \\
\hline Emphases on short-term objectives & & & & $\mathrm{x}$ & & & & & & & & & & & & & & & & \\
\hline Cost and time implementation & & & & $\mathrm{x}$ & & & & & & & & & & & & & & & & \\
\hline Design complexity & & & & & $\mathrm{x}$ & & & & & $\mathrm{x}$ & & & & & & & & & & \\
\hline Quality policy & & & & & & $\mathrm{x}$ & $\mathrm{x}$ & & & & & & & & & & & & & \\
\hline Project supervision & & & & & & $\mathrm{x}$ & & $\mathrm{x}$ & & & & & & & & & & & & \\
\hline Auditing system & & & & & & & & & & & & $\mathrm{x}$ & & $\mathrm{x}$ & & & & & & \\
\hline Subcontractor's responsibility & & & & & & & & $\mathrm{x}$ & & & & $\mathrm{x}$ & & & & & & & & \\
\hline Nature uniqueness & & & & & $\mathrm{x}$ & & & & & & & & & & & & & & & $\mathrm{x}$ \\
\hline Availability of resources & & & & & $\mathrm{x}$ & & $\mathrm{x}$ & & & & & & & & $\mathrm{x}$ & & & & & \\
\hline Project environment & & & & & $\mathrm{x}$ & & & & & & & & & & & & & & & \\
\hline
\end{tabular}


Joaquin et al. (2008) spell out quality problems as low quality continuous improvement, lack of quality policy and poor availability of resources. Wong and Fung (1999) point out project supervision and subcontractor responsibility as critical factors influencing quality performance. Reduced subcontractor responsibility, inappropriate bid selection method, lack of auditing system, low quality continuous improvement and lack of motivation are listed as quality problems (Pheng and Wei, 1996). Marosszeky et al. (2002) identify quality setbacks as poor organization structure, lack of motivation, poor management commitment and poor teamwork. Other previous studies have identified quality factors as coordination between project participants, expertise knowledge/ training, design complexity, subcontractor responsibility, planning process, auditing system, management commitment, availability of resources, incentives and nature uniqueness (Jha and Iyer, 2006; Tang et al., 2009; Leonard, 2008; Moody, 2005; Saraph et al., 1989; Samuels, 1994; Hiyassat, 2000; Yung and Yip, 2010; Mohammed and Abdullah, 2006; Serpell, 1999; Kanji and Wong, 1998). Table II denotes the summary of factors influencing quality management in construction projects.

\section{METHODOLOGY}

\section{A. Questionnaire Design}

The exploratory nature of this study requires a combination of both quantitative and qualitative methods of data collection. For quantitative approach, surveys through questionnaires were found effective because of the relative ease of obtaining standard data appropriate for achieving the aim of the study. This approach involves the administration of structured questionnaire to consultants, consultants and subcontractors practising in the study area. From the literature scan, a number of 22 safety factors and 27 quality factors were selected and used to design the questionnaire to determine the crucial factors of both safety and quality issues. In order to achieve this, the respondents are expected to rank each factor using Likert scale of four ranging from 0 for never occurred to 4 for Always. Pilot studies were carried out to ensure clarity and relevance of the drafted questionnaire. The drafted questionnaire was reviewed by four professionals in the research field. The two professionals were university professors while the other two were researchers in the related field and working in the construction industry. Amendments were made on the drafted questionnaire based on the suggestions of the reviewers. The questionnaire was administered to the respondents using face to face method to ensure validity of their responses. According to Farrell (2011), the use of qualitative method for data collection may be difficult to get an answer but the data captured are rich. Personal interviews were conducted with some respondents to clarify their answers.

\section{B. Characteristics of Respondents}

The study population comprises of construction firms who are involved in both building and civil engineering works in Akwa Ibom State of Nigeria. Akwa Ibom is an oil rich state with the largest allocation of oil revenue. For the past five years, the state has experienced the largest infrastructural development in Nigeria, thus has also increased the demand for best performance. Akwa Ibom state has been recognized by both local and international bodies for rapid development which has earned the present administration several awards for its gigantic efforts. The signing of Nigeria's National Building Code (NBC) into law in 2007 has increased the demand of adequate safety, health and quality in construction. However, unofficial statistics show that more safety related incidents and more buildings have collapsed year to year since 2007. The struggle to enforce the law has led to demand of possible solutions to work-related accidents and injuries in construction projects. Kothari (2003) stipulates that survey protocol of random sampling procedures allows a relatively small number of people to represent a much larger population. The study targeted a total of number of 10 construction companies registered with Ministry of Works and Housing, Akwa Ibom State under the grade of $\mathrm{C}$ to $\mathrm{D}$, who are actively involved in on-going projects. This study targeted 220 construction professionals working on the project site. A total of number of 40 professionals did not respond due to tight schedule, thereby reducing the population size to 180 professionals. The demographic data of the respondents shows that 50 percent of subcontractors, 42 percent of contractors and 8 percent of consultants. This reveals that majority of the respondents as actively involved in construction projects as subcontractors. The data reveals the working experience of respondents below 5 years $(30$ percent), between 5 to 9 years (13 percent), between 10 to 15 years (51 percent) and above 15 years (6 percent). This discloses that a large proportion of respondents have between $10-15$ years of working experience in construction industry, their ample experiences are of great value to this research. The survey shows 56 percent of the respondents are experienced in both building/ industrial and bridge/ road projects.

\section{Method of Data Analysis}

This section is to seek the preferences of respondents on crucial factors influencing safety and quality management on construction sites. Evaluation of data is calculated using the formula;

$T W V=\sum_{i=1}^{4} \mathrm{PiVi}$

Where TWV is the total weight value, Pi is the number of respondents rating the safety and quality factors $i$ and $V i$ is the weight assigned to each factor $i$. The factor index (FI) for each factor is derived by dividing TWV by the number of respondents (n) and the mean of FI is also determined ( see equation 2).

$F I=\sum_{i=1}^{4} \frac{\mathrm{PiVi}}{\mathrm{n}}$ 
The absolute deviation from the mean of each factor, variance and standard deviation of the distribution are calculated to measure the scatter about the mean. The variance is computed using the formula;

Variance $=\sum\left(\frac{\mathrm{FI}-\mu}{\mathrm{N}}\right) 2$

For safety factors, the Variance is 0.392 and the Standard Deviation is 0.626 , the highest score is 3.712 and the lowest score is 1.684 with a spread of 2.028 . The variance for quality factors is 0.454 , the Standard Deviation is 0.674 , the highest score is 3.692 and the lowest score is 0.860 with a spread of 2.832 .

\section{RESULTS AND DisCUSSIONS}

The Pareto rule states that the highest ranked has the greatest influence, assumptions were made based on this rule. Table III reveals the three most crucial factors influencing safety management in construction projects as management commitment, safety awareness of top management practices/ procedure/ review, and errors in judgment or carelessness. The results show that management commitment is essential for effective safety management. This is in line with study conducted by
Gillen et al. (2004), which stipulates that company managers play a pivotal role in the definition and implementation of safety practices in the workplace and employees look up to them for guidance and modelling. A sincere commitment by management and consistency in enforcement of safety rules are foundations for effective safety program. The safety awareness is ranked second, the safety culture in the industry is just like any other organisation ... which assists in reducing risks involved to the employees' health and life, thereby increasing the awareness among employees with the help of positive leadership and strategic planning from the management of the organisation' (Bernard, 2011). The safety awareness amongst top managers will enable effective transmission of safety programs to the actual players (employees). Errors in judgment or carelessness is ranked third, this is generally accepted by the respondents that decisions taken by project participants can greatly influence the safety management in projects. Decision making is a crucial aspect in project implementation. The least important factor is concerned as audits and observations. Most respondents believed that audits and observations of work progress can only play little or no significant influence in safety procedure.

TABLE III

FACTORS INFLUENCING SAFETY MANAGEMENT IN CONSTRUCTION PROJECTS

\begin{tabular}{l|c|c|c|c}
\hline \multicolumn{1}{c|}{ Safety Factors } & $\begin{array}{c}\text { Factor index } \\
(\mathrm{FI})\end{array}$ & Rank $^{\text {st }}$ & $\begin{array}{c}\text { Mean } \\
\text { Deviation }\end{array}$ & $(\mathrm{FI}-\mu)^{2}$ \\
\hline Management commitment & 3.712 & $1^{\text {st }}$ & 0.934 & 0.872 \\
\hline Employee involvement/ altitude & 2.108 & $16^{\text {th }}$ & -0.670 & 0.449 \\
\hline Errors in judgment or carelessness & 3.568 & $3^{\text {rd }}$ & 0.790 & 0.624 \\
\hline Expertise knowledge or training & 3.536 & $4^{\text {th }}$ & 0.758 & 0.575 \\
\hline Poor machineries & 3.520 & $5^{\text {th }}$ & 0.742 & 0.551 \\
\hline Communication & 2.604 & $14^{\text {th }}$ & -0.174 & 0.030 \\
\hline Audit/ observations & 1.684 & $20^{\text {th }}$ & -1.094 & 1.197 \\
\hline Safety culture/climate & 3.128 & $8^{\text {th }}$ & 0.350 & 0.123 \\
\hline Safety awareness of top management/ project managers & 3.616 & $2^{\text {nd }}$ & 0.838 & 0.702 \\
\hline Reluctance of input resources to safety & 2.896 & $10^{\text {th }}$ & 0.118 & 0.014 \\
\hline Safety policy/ arrangement & 2.724 & $12^{\text {th }}$ & -0.054 & 0.003 \\
\hline Safety management practices/ procedure/ review & 2.100 & $18^{\text {th }}$ & -0.678 & 0.460 \\
\hline Type and nature of construction & 1.928 & $19^{\text {th }}$ & -0.850 & 0.773 \\
\hline Client involvement & 3.416 & $6^{\text {th }}$ & 0.638 & 0.407 \\
\hline Insurance company requirement & 2.892 & $11^{\text {th }}$ & 0.114 & 0.013 \\
\hline Cost effectiveness/ time & 2.616 & $13^{\text {th }}$ & -0.162 & 0.026 \\
\hline Tight project schedule & 3.248 & $7^{\text {th }}$ & 0.470 & 0.221 \\
\hline Improper construction planning/ procedure & 2.972 & $9^{\text {th }}$ & 0.194 & 0.038 \\
\hline Variations & 2.616 & $13^{\text {th }}$ & -0.162 & 0.026 \\
\hline Lack of coordination between project participants & 2.192 & $15^{\text {th }}$ & -0.586 & 0.343 \\
\hline Employee empowerment & 1.928 & $19^{\text {th }}$ & -0.850 & 0.723 \\
\hline Emphases on short objectives & 2.104 & $17^{\text {th }}$ & -0.674 & 0.454 \\
\hline
\end{tabular}

From Table IV, the three crucial factors influencing quality management were considered as project supervision, employee involvement and altitude and finally expertise knowledge or training. Supervision of construction works involves coordination of activities to ensure completion on time, on budget, and compliancy with the relevant quality standards. The quality of supervision is fundamentally important to ensure construction quality measures. The behavioural pattern of project employees has a major role to play in project productivity or output. The analysis ranks employee involvement and attitude to work as second highest factor influencing quality management. Employee attitudes are crucial for an organisation, since they usually influence 
the employees' inputs or efforts. A positive attitude exists when there is job satisfaction while dissatisfaction exists when the attitude is negative. Positive attitude and involvement is most likely to lead to $\mathrm{n}$ inner commitment to improved performance (Moorhead and Griffin, 1992). For complex and larger projects, a construction company may not have all the required expertise. In specialized areas, it is important to employ an expert in the related field to manage the work element. The study shows that the quality of a project can be enhanced through proper involvement of experts in the relevant areas; this is ranked as the third factor.

TABLE IV

FACTORS INFLUENCING QUALITY MANAGEMENT IN CONSTRUCTION PROJECTS

\begin{tabular}{|c|c|c|c|c|}
\hline Quality Factors & $\begin{array}{l}\text { Factor index } \\
(\mathrm{FI})\end{array}$ & Rank & $\begin{array}{c}\text { Mean } \\
\text { Deviation }\end{array}$ & $(\mathrm{FI}-\mu)^{2}$ \\
\hline Management/ leadership skills & 3.332 & $7^{\text {th }}$ & 0.454 & 0.206 \\
\hline Interpretation of client/ customer expectation & 3.036 & $13^{\text {th }}$ & 0.158 & 0.025 \\
\hline Worker empowerment through incentive & 3.112 & $12^{\text {th }}$ & 0.234 & 0.054 \\
\hline Organization structure & 2.632 & 20th & -0.246 & 0.061 \\
\hline Teamwork & 3.224 & $9^{\text {th }}$ & 0.346 & 0.120 \\
\hline Continuous improvement & 3.152 & $11^{\text {th }}$ & 0.274 & 0.075 \\
\hline Management commitment & 2.896 & $17^{\text {th }}$ & 0.018 & 0.000 \\
\hline Communication & 3.243 & $8^{\text {th }}$ & 0.365 & 0.133 \\
\hline Client/ customer focus & 3.404 & $6^{\text {th }}$ & 0.526 & 0.277 \\
\hline Employee involvement/ altitude & 3.604 & $2^{\text {nd }}$ & 0.726 & 0.527 \\
\hline Tight project schedule & 1.912 & $22^{\text {nd }}$ & -0.966 & 0.933 \\
\hline Inaccurate or incomplete cost estimate & 3.416 & $5^{\text {th }}$ & 0.538 & 0.289 \\
\hline Variations & 2.896 & $17^{\text {th }}$ & 0.018 & 0.000 \\
\hline Improper planning/ scheduling & 2.576 & $21^{\mathrm{st}}$ & -0.302 & 0.091 \\
\hline Coordination between project participants & 3.024 & $14^{\text {th }}$ & 0.146 & 0.021 \\
\hline Expertise knowledge and training & 3.560 & $3^{\text {rd }}$ & 0.682 & 0.465 \\
\hline Tendering/bidding climate & 3.224 & $9^{\text {th }}$ & 0.346 & 0.120 \\
\hline Emphases on short term objectives & 3.168 & $10^{\text {th }}$ & 0.290 & 0.084 \\
\hline Cost and time implementation & 1.388 & $24^{\text {th }}$ & -1.490 & 2.220 \\
\hline Design complexity & 3.424 & $4^{\text {th }}$ & 0.546 & 0.298 \\
\hline Quality policy & 2.904 & $16^{\text {th }}$ & 0.026 & 0.001 \\
\hline Project supervision & 3.692 & $1^{\mathrm{st}}$ & 0.814 & 0.663 \\
\hline Auditing system & 2.660 & $19^{\text {th }}$ & -0.218 & 0.048 \\
\hline Subcontractors responsibility & 3.016 & $15^{\text {th }}$ & 0.138 & 0.019 \\
\hline Nature uniqueness & 0.860 & $25^{\text {th }}$ & -2.018 & 4.072 \\
\hline Availability of resources & 2.680 & $18^{\text {th }}$ & -0.198 & 0.039 \\
\hline Project environment & 1.684 & $23^{\text {rd }}$ & -1.194 & 1.426 \\
\hline
\end{tabular}

\section{CONCLUSIONS}

The research survey demonstrated that safety and quality management is a vital tool in improving performance, profitability and productivity during project implementation. In the literature scan, the study identified a total number of 22 safety factors and 27 quality factors which was evaluated. The result reveals the three most crucial factors influencing safety management in construction projects as management commitment, safety awareness of top management practices/ procedure/ review, and errors in judgment or carelessness. The quality management is crucially influenced by the three most factors, which are project supervision, employee involvement and altitude and finally expertise knowledge or training. The study discloses that safety and quality issues are essential to achieve project success. More so, it has also exposed the critical factors to be considered in managing both safety and quality issues. Future work is recommended in both developing and developed countries for comparison purposes.

\section{REFERENCES}

[1] T.S. Abdelhamid, J.G. Everett, "Identifying root causes of construction accidents", Journal of Construction Engineering and Management, ASCE, vol. 126, no. 1, pp. 52 -60, 2000.

[2] S.I. Abdul Raouf, "Productivity enhancement using safety and maintenance integration an overview", Kybernetes, vol. 33, no. 7, pp. 1116- 1126, 2004.

[3] C. Anumba, G. Atkinson, "Importance of Safety considerations in Site Layout and Organization", Canadian Journal of Civil Engineering, vol. 24, no. 2, pp. 229- 236, 1997.

[4] D. Arditi, H.M. Gunaydin, "Factors that affect process quality in the lifecycle of building projects", Journal of Construction Engineering and Management, ASCE, vol. 124, no. 3, pp. 194-203, 1998.

[5] C. Ashmore, "Health and safety management: turning liabilities into assets", Engineering Management Journal, vol. 5, no. 2, pp. 52-56, 1995.

[6] E.V. Barlett, M. Cliff, "Reliability and Whole Life performance: Integrating the Supply Chain", Unpublished M.Sc. thesis, Westminster University, England, 1999.

[7] A.P.C. Chan, C.M. Tam, "Factors affecting the quality of building projects in Hong Kong", International Journal of Quality and Reliability Management, vol. 17, no. 4/5, pp. 423-441, 2000.

[8] R.I. Coble, C. J. Kibert, "The environment as a construction Safety Concern", Proceedings of the $5^{\text {th }}$ Annual Rinker International Conference focusing on Construction Safety and Loss Control, Florida, pp. 535-540, 1994. 
[9] Construction, Engineering and Infrastructure Management, "Reasons for construction accidents in Vietnam", Professional Project Management Education, Asian Institute of Technology, Thailand, 2010.

[10] M.D. Cooper, R.A. Phillips, "Killing two birds with one stone: Achieving Quality via Total Safety Management", Leadership and Organisational Development Journal, vol. 16, no. 8, pp. 3-9, 1995.

[11] U.S. Department of Labor's Employment and Training Administration (ETA), "America's Construction Industry: Identifying and addressing workforce challenges", ETA/ Business Relations Group Report, 2004.

[12] European Process Safety Centre, "Safety Management Systems: Sharing Experiences in Process Safety", Institution of Chemical Engineers, London, 1994.

[13] Federal Ministry of Works and Housing Development, "Analysis of Construction Fatalities", U.S. Department of Labor's Occupational Safety and Health Administration, Washington, D.C., 2007.

[14] L. Harms-Ringdahl, T. Jansson, Y. Malmen, "Safety, health and environment in small process plants: results from a European survey", Journal of Safety Research, vol. 31, no. 2, pp. 71-80, 2000.

[15] M.A.S. Hiyassat, "Applying the ISO standard to a construction company: A case study", International Journal of Project Management, vol. 18, no. 4, pp. 275-280, 2000.

[16] P.L.T. Hoonakker, "Quality management in Construction Industry", Proceedings of ASQ World Conference on Quality and Improvement, Milwaukee, WI, USA, pp. 1 -9, 2006.

[17] P.L.T. Hoonakker, T. Loushine, J. Kallman, P. Carayon, A. Kapp, M.J. Smith, "Accidents, Injuries, Worker's compensation, Safety and Safety Policy in Construction Industry: The effort/results paradox", Proceedings of the International Ergonomics Association (IEA) Conference, Seoul, Korea, 2003.

[18] N.H. Husin, H. Adnan, K. Jusoff, "Management of Safety for Quality Construction”, Journal of Sustainable Development, vol. 1, no. 3, pp. 41- 47, 2008.

[19] K.N. Jha, K.C. Iyer, "Critical factors affecting Quality Performance in Construction Projects", Total Quality Management, vol. 17, no. 9, pp. 1155-1170, 2006.

[20] D. Joaquin, D. Hernandez, E. Aspinwall, “A framework for building quality into construction projects- Part I", Total Quality Management, vol. 19, no. 10, pp. 1013-1028, 2008.

[21] G.K. Kanji, A. Wong, "Quality culture in the construction industry", Total Quality Management, vol. 9, no. 4, pp. 133-140, 1998.

[22] T.R. Krause, "Safety and Quality: Two sides of the same coin", Quality Progress, vol. 27, no. 10, pp. 51-55, 1994.

[23] J.A. Kuprenas, M.D. Kenney, "Total quality management implementations and results: Progress update", Practice Periodical on Structural Design and Construction, vol. 3, no. 1, pp. 34-39, 1998.

[24] W.K. Law, A.H.S. Chan, K.F. Pun, "Prioritizing the safety management elements: A hierarchical analysis for manufacturing enterprises", Industrial Management and Data Systems, vol. 106, no. 6, pp.778-792, 2006.

[25] D. Leonard, "Quality management practices in the US homebuilding industry", The TQM Journal, vol. 22, no. 1, pp. 101$110,2008$.

[26] T.W. Loushine, P.L.T. Hoonakker, "Integrated Quality and Safety Management Systems in Construction", Proceedings of the 12th Annual Construction Safety Conference, Chicago, IL, USA, 2002.

[27] R.T.M. Marosszeky, K. Karim, S. David, D. McGeorge, "The importance of project culture in achieving quality outcomes in construction", Proceedings of the International Group for Lean Construction (IGLC), Gramado, Brazil, 2002.

[28] R.A. McKim, H. Kiani, "Applying total quality management to the North American construction industry", Cost Engineering, vol. 37, no. 3, pp. 24-29, 1995.

[29] A.H.B. Mohammed, M.N.B. Abdullah, "Quality management system in construction", Proceedings of the International Conference on Construction Industry (ICCI), Malaysia, 2006.

[30] D.L. Moody, "Theoretical and practical issues in evaluating the quality of conceptual model: current state and future directions", Data and Knowledge Engineering, vol. 55, no. 3, pp. 243-276, 2005.
[31] A.C. Ogwueleka, "Stochastic Dominance in Projects", International Journal of Project Organisation and Management, vol. 2, no. 2, pp. 208-217, 2010.

[32] A.C. Ogwueleka, "The Critical Success Factors influencing Project Performance in Nigeria", International Journal of Management Science and Engineering management, vol. 6, no. 5, pp. 343 -349, 2011.

[33] L.S. Pheng, P.K. Wei, "A framework for implementing TQM in construction", Total Quality Management, vol. 8, no. 5, pp. 39-46, 1996.

[34] R. Pollo, "Service Life and LCC Assessment: the use of FMEA as Design Tool", Proceedings of International Workshop on Management of Durability in the Building Process, Milan, 2003.

[35] K.F. Pun, J.K. Hui, "Integrating safety dimension in Quality dimension in Quality management systems: a process model", Total Quality Management, vol. 13, no. 3, pp. 373-391, 2002.

[36] P.O. Saksvik, K. Nytro, "Implementation of internal control of health, environment and safety in Norwegian enterprises", Safety Science, vol. 23, no. 1, pp. 53-61, 1996.

[37] A.F. Samuels, "Construction facilities audit: quality systemperformance control", Journal of Management in Engineering, ASCE, vol. 10, no. 4, pp. $60-65,1994$.

[38] J.V. Saraph, P.G. Benson, R.G. Schroeder, "An instrument for measuring the critical factors of quality management", Decision Science, vol. 20, no. 4, pp. 810-829, 1989.

[39] J. Schriener, J.W. Angelo, R. McManamy, "Total quality management struggles into a low orbit”, Engineering NewsRecord, vol. 234, no. 19, pp. 24-28, 1995.

[40] A. Serpell, "Integrating quality systems in construction projects: the Chilean case", Management, vo. 17, no. 5, pp. 317-322, 1999.

[41] J.J. Smallwood, "The holistic influence of design on construction health and safety (H\&S): General contractor (GC) perceptions", Proceedings of the Designing for Safety and Health Conference, London, UK, pp. 27-35, 2000.

[42] S. Sousa, J. Teixeira, "Prevention measures to reduce risk of falling from heights", IX National Symposium of ISMAI, Porto, Portugal, 2004.

[43] J. Stanley, "The causes of construction accidents and what to do about them", Workplace Safety Blog, 2010.

[44] D.A. Stewart, A.S. Townsend, "There is more to "health and safety is good businesses' than avoiding unplanned costs", 1999, www.behavioralsafety.com, retrieved on 22/06/2012.

[45] C.M. Tam, S.X. Zeng, Z.M. Deng, "Identifying Elements of Poor Construction Safety Management in China", Safety Science, vol. 42 , no. 7, pp. $569-586,2004$.

[46] A. Wong, P. Fung, "Total quality management in the construction industry in Hong Kong: A supply chain management perspective", Total Quality Management, vol. 10, no. 2, pp. 199-208, 1999.

[47] M. Gillen, S. Kools, J. Sum, C. McCall, K. Moulden, "Construction Workers Perceptions of Management Safety Practices: a qualitative investigation", Journal of Prevention Assessment and Rehabilitation, vol. 23, no. 3, pp. 245 -256, 2004.

[48] S. Bernard, "Importance of Safety Culture in Construction", 2011, www.essaytube.com, retrieved on May $12^{\text {th }}, 2013$.

[49] G. Moorhead, R.W. Grffin, "Organizational Behavior", $3^{\text {rd }}$ ed., Boston: Houghton Mifflin Company, 1992. 